\title{
Analysis of seed yam varieties, sources and quantity demanded by farmers in major yam producing districts in Ghana
}

\author{
P. BOADU*, R. AIDOO, K. OHENE-YANKYERA, U. KLEIH, T. ABDOULAYE, J. \\ ORCHARD, N. MAROYA, M. OWUSU \& S. BEKOE
}

(P.B \& M.O.: CSIR-Science and Technology Policy Research Institute, Agricultural, Medicine, and Environment Division, Accra, Ghana; R.A \& K.O-Y.: Kwame Nkrumah University of Science and Technology (KNUST), Department of Agricultural Economics, Agribusiness and Extension, Kumasi, Ghana; U.K \& J.O.: University of Greenwich, Natural Resources Institute, Medway Campus, Central Avenue, Chat-ham maritime, Kent, ME4 4TB, United Kingdom; T.A \& N.M.: International Institute of Tropical Agriculture (IITA), Ibadan, Nigeria; S.B.: CSIR-Institute of Scientific and Technological Information, Accra, Ghana)

*Corresponding author's email: boadu@myself.com/pboadu@csir-stepri.org

\begin{abstract}
The study analysed the varieties, sources and quantities of seed yam demanded by farmers for cultivation in order to inform policies aimed at ensuring adequate supply of quality seed yam of desirable varieties at an affordable price to boost yam productivity for improved income and livelihoods. A structured questionnaire was administered to 380 randomly selected yam farmers in three major yam producing districts in Ghana in 2015. The data analysis was done using STATA statistical software. The study identified Pona/Punjo, Lariboko, Asana, Afebetuye, Dente, Olondo and Kparinjo as the yam varieties mainly cultivated by farmers in a reducing order with high market demands by consumers. Own production remains the major source of seed yam for farmers. The estimated monetary value of quantity of seed yam used by farmers for cultivation in 2014 farming season was GHc 198, 552,841.0 (USD 51,706,469.0) in the study locations. About GHф 5,679,979.0 (USD 1,479,161.2) worth of quantities of seed yam was obtained from the market and other sources. The results demonstrate the existence of market potential for commercial seed yam production and supply in Ghana. Commercial seed yam certification system and yam breeding activities should target the identified yam varieties.
\end{abstract}

Keywords: Seed yam; seed sources; quantity demanded; certification system; commercial seed system

Original scientific paper. Received 04 Apr 19; revised 01 Oct 19

\section{Introduction}

Yam (Diocsorea ssp.) is a vital crop in the West African sub-region. Daily utilization of yam per capita is high in Benin, Côte d'Ivoire,
Ghana and Nigeria with estimated quantity of 364, 342, 296, and $258 \mathrm{kcal}$, respectively (Nweke et al., 2013). Yam is the third most vital provider of energy in Ghanaian food. It

Ghana Jnl Agric. Sci. 54 (2), $45-57$

GJAS is an Open Access Journal and distributed under the terms of the Creative Commons (CC) License [CC BY 4.0] 
accounts for about $20 \%$ of aggregate caloric consumption (Nweke et al., 2013 )This shows the irreplaceable popularity of the crop in the West African sub-region. Yam is important commodity in both domestic and international markets, but domestic markets drive the value chain (Otoo et al., 2013). Sale prices of ware yam have seen a tremendous increase over the years. Various authors have argued that the increases in the prices of yam are not only because of increase in disposable incomes due to economic growth but also population growth and increased demand from countries within the sub-region and beyond (MiDA, 2010; MEDA, 2011; Otoo et al., 2013). Therefore, low-income households find consumption of yam relatively unaffordable compared to other roots and tubers such as cassava, cocoyam and taro (Aidoo, 2009; IITA, 2014).

Seed is the most fundamental input in crop production (Ghimire et al., 2012; Badstue et al., 2006) and serves as important source of germ-plasm for crop improvement, management and conservation of genetic resources (Bellon, 2004; Almekinders, 2001; Almekinders \& de Boef, 2000; Jarvis et al., 2000). Farm productivity depends, to a greater extent, on good quality seed of desirable variety planted by farmers (Cromwell, 1990). Consequently, the sources of seed of the desired varieties and of good quality are therefore major concerns to farmers and society at large in the quest to achieve food security and to end hunger as unambiguously stated in Goal 2 (2015) of UN 2030 Sustainable Development Goal (SDGs).

Although seed accounts for a minor portion of the total production costs of majority of crops (Ghimire et al., 2012; Verma \& Sidhu, 2009), that case of yam production is on the contrary as the cost of seed yam constitutes over 45 percent of production costs (Aighewi \& Maroya, 2013; Ezeh, 1991; Asumugha et al., 2008). Quality seed is required to obtain the needed productive yield, given other complementary inputs (Singh et al., 1990). The lack and availability of quality seed yam pose major limitations to production, which is an important food and cash crop, in the West African sub-region (Mignouna et al., 2014b). In the absence of certified seed yam system to supply quality seed to yam farmers, farmers rely on traditional methods to produce seed yam for cultivation. This involves "milking" or harvesting the yam tubers (also known as ware yam) early and using some portion of the seed yams that result from the process for planting; cutting smaller tubers into 250-500 g; using the head portion of tubers only or the use of small whole tuber from ware yam production (Aighewi et al., 2014).

The traditional methods of seed yam production (own production) are however constrained by low multiplication ratio (1:4-1:8), unavailability of seed yam for first-time growers, and encourages the spread of diseases. The process also requires the use of high proportion (up to $30 \%$ ) of ware yam as seeds, which reduces the quantity of yam available for sale and consumption (Otoo, 2003; Otoo et al., 2013; Aighewi et al., 2013; Aighewi \& Maroya, 2013). Consequently, there are ongoing efforts by donor agencies, international organizations in collaboration with the Government of Ghana to establish commercial seed yam certification system to ensure sustainable supply of quality seed yam to boost yam production. Seed system is the process by which producers obtain seeds required for cultivation. It may involve production, selection, saving and/or procurement of seed from diverse sources (Sthapit et al., 2008). Ragassa (2000) opined that sustainable 
agricultural development is dependent on the availability of regular supply of quality seeds and complementary input supply to smallholder farmers. According to Tripp (2003), until smallholder farmers are connected to inputs and produce markets, they will produce their own seeds and/or procure surpluses seed from other farmers. Various authors (Louwaars \& De Boef, 2012; Tripp, 2003; ICRISAT, 2009) have stated that seed system in commercial growth perspective is essential to supply quality seeds for various crop varieties to meet the increasing consumer demands as well as industrial needs.

The establishment and smooth operation of commercial seed yam certification system would be dependent, among others, on knowledge about major varieties cultivated by farmers, sources and quantities of seed yam obtained from such sources. The former has implications for yam-breeding activities, while the later could provide market signals for commercial seed producers to participate in seed yam production and supply. In view of these, this paper is set out to:

- Identify yam varieties cultivated by farmers in major yam producing districts in Ghana

- Identify the sources and quantities of seed yam obtained from such sources; and

- $\quad$ Estimate and predict quantity of seed yam demanded by farmers in the major yam producing districts in Ghana.

\section{Materials and methods}

The data used for this paper were obtained from a field survey conducted in 2015 in Kintampo (transition agro-ecology), East Gonja (guinea savannah) and Afram Plains (deciduous forest zone) districts, located in Brong Ahafo, Northern and Eastern regions, respectively, in Ghana.
The three regions from which three districts were selected together contribute about $76 \%$ of yam production in Ghana (Anaadumba, 2013). After purposive selection of the three districts based on production and distribution across different agro-ecological zones, five communities were randomly selected from a sample frame of major yam producing communities obtained from the District Agricultural Development Units of the District Assemblies in the study locations. At the community level, listing of houses and households was conducted to provide sampling frame of yam farmers. With the aid of the sampling frame, simple random sampling was used to select at least 25 yam farmers per community for the study. A total of 380 yam farmers responded to the survey questionnaire. The survey was conducted in August 2015.

The quantity of seed yam demanded (in monetary terms) by farmers from various sources was estimated using equation 1:

Where:

$$
\left.Q_{d}=\Sigma\left[Q_{i}^{*} V_{i}\right)\right]
$$

$Q_{d}$ is monetary value of quantity of seed yam demanded by farmers;

$Q_{i}$ is the quantity of seed yam obtained by farmers in bunches (A bunch of seed yam is made up of 100 pieces of seed yam, seed yam are classified into small $(45 \mathrm{~kg})$, medium $(84 \mathrm{~kg})$ and large size $(180 \mathrm{~kg})$. A bunch of large size seed yam could be divided into a minimum of 5 pieces each of $300 \mathrm{~g}$; a bunch of medium size seed yam could be divided into three pieces of $300 \mathrm{~g}$ each; and a maximum of 150 pieces of $300 \mathrm{~g}$ could be obtained from a bunch of small seed yam); and

$\mathrm{V}_{\mathrm{i}}$ is the value/ market price of seed yam at a given time 


\section{Results and discussions}

The socio-economic characteristics of yam farmers are presented in Table 1 . The results show that $96.3 \%$ of all the respondents were males and the remaining, females. The results corroborate the findings of Otoo et al.
(2013) and Mignouna et al. (2014a) that male dominate yam activities at the production level. The data did not show much variation in terms of gender distribution across yam farmers in the study locations. Males were $96.8 \%, 95.5 \%$ and $98.8 \%$, in the Kintampo, East Gonja and Afram Plain districts, respectively.

TABLE 1

Socio-economic characteristics of yam farmers

\begin{tabular}{|c|c|c|c|c|c|c|c|c|c|}
\hline \multirow[b]{2}{*}{ Variable } & \multicolumn{2}{|c|}{$\operatorname{All}(N=380)$} & \multicolumn{2}{|c|}{$\begin{array}{l}\text { Kintampo district } \\
(N=123)\end{array}$} & \multicolumn{2}{|c|}{$\begin{array}{l}\text { East Gonja district } \\
(N=133)\end{array}$} & \multicolumn{3}{|c|}{ Afram Plains district $(N=124)$} \\
\hline & Freq. & $\%$ & Freq. & $\%$ & Freq. & $\%$ & & Freq. & $\%$ \\
\hline \multicolumn{10}{|l|}{ Sex } \\
\hline Male & 366 & 96.3 & 119 & 96.8 & 127 & 95.5 & & 120 & 96.8 \\
\hline Female & 14 & 3.7 & 4 & 3.3 & 6 & 4.5 & & 4 & 3.2 \\
\hline \multicolumn{10}{|l|}{ Age group } \\
\hline$<30$ & 47 & 12.4 & 10 & 8.1 & 33 & 24.8 & & 4 & 3.2 \\
\hline $30-49$ & 203 & 53.5 & 69 & 56.1 & 63 & 47.4 & & 71 & 57.3 \\
\hline $50+$ & 130 & 34.3 & 44 & 35.7 & 37 & 27.8 & & 49 & 39.6 \\
\hline Mean & & 45.2 & & 47.6 & & 40.9 & & & 47.5 \\
\hline \multicolumn{10}{|c|}{ Educational level } \\
\hline None & 315 & 82.9 & 98 & 79.7 & 121 & 91.0 & & 96 & 77.4 \\
\hline Basic & 49 & 12.9 & 18 & 14.6 & 5 & 3.8 & & 26 & 21.0 \\
\hline Secondary & 14 & 3.7 & 6 & 4.9 & 6 & 4.5 & & 2 & 1.6 \\
\hline Tertiary & 2 & 0.5 & 1 & 0.8 & 1 & 0.8 & & 0 & 0.0 \\
\hline \multicolumn{10}{|c|}{ Experience in yam (years) } \\
\hline $1-5$ & 55 & 14.5 & 26 & 21.1 & 19 & 14.3 & & 10 & 8.1 \\
\hline $6-10$ & 68 & 17.9 & 20 & 16.3 & 26 & 19.6 & & 22 & 17.7 \\
\hline $11+$ & 257 & 67.6 & 77 & 62.6 & 88 & 66.2 & & 92 & 74.2 \\
\hline \multicolumn{10}{|c|}{ Yam farm size (hectares) } \\
\hline$<2$ & 236 & & 62.1 & 72 & 58.5 & 91 & 68.4 & 73 & 58.9 \\
\hline $2-5$ & 125 & & 32.9 & 38 & 30.9 & 41 & 30.8 & 46 & 37.1 \\
\hline$>5$ & 19 & & 5.0 & 13 & 10.6 & 1 & 0.8 & 5 & 4.0 \\
\hline Mean & 2.1 & & & 2.6 & & 1.7 & & 1.9 & \\
\hline \multicolumn{10}{|c|}{ Income level (Ghc) } \\
\hline$<3000$ & 142 & 37.4 & 55 & 44.7 & 66 & 49.6 & & 21 & 16.9 \\
\hline $3,001-6,570$ & 103 & 27.1 & 33 & 26.8 & 38 & 28.6 & & 32 & 25.8 \\
\hline $6,571-25,200$ & 105 & 27.6 & 24 & 19.5 & 26 & 19.6 & & 55 & 44.4 \\
\hline$>25,200$ & 30 & 7.9 & 11 & 8.9 & 3 & 2.3 & & 16 & 12.9 \\
\hline
\end{tabular}

Source: Field survey, 2015

The results show that the majority of the respondents were between the age group of 3049 years. About $53.5 \%$ of all respondents were in this age category with an overall average age of 45.2 years. This result corroborates the findings of Mignouna et al. (2014a). Similar distributions of age group were observed across the three districts with variations in mean ages. While the average age of respondents was about 47.5 years in both Kintampo and Afram 
Plains districts, that of the East Gonja district was a little lower, about 40.9 years (Table1). Also, the overall sample shows that only about $12.4 \%$ of the respondents were below 30 years. The proportion of respondents who were below 30 years ranged from $24.8 \%$ in the East Gonja district, $8.1 \%$ in the Kintampo district to a minimum of $3.2 \%$ in the Afram Plains district. About $82.9 \%$ of all the respondents had no formal education. The proportion was even higher in the East Gonja district, where as high as $91.0 \%$ of the respondents did not have any formal education. The proportion of respondents who had no formal education was similar in the Kintampo and Afram Plain district, about 78\%. Respondents with basic level of education were about $12.9 \%$, while those with secondary or higher level of education were less than $5 \%$ of the total sample of the study.

Regarding land allocation to yam production, the results show an average yam farm size of 5.2 acres (2.1 ha). The yam farm size of the majority of farmers $(62.1 \%)$ was below 5 acres (2.0 ha). Also, the highest average yam farm size of 6.4 acres (2.6 ha) was recorded among farmers in the Kintampo municipality. This is about 0.8 hectares bigger than that operated by farmers in the East Gonja and Afram Plains district. Access to the market might have accounted for the variations.

Household annual income comprises income from employment, agricultural and nonfarm activities, rent, remittances, and income from other sources. Following the Ghana Living Standards Survey Six (GLSS6) report, the respondents' annual household incomes were classified into three income groups (i.e. low, middle and high). The low-income households have average annual income of $\mathrm{GH} \phi 6,571.8$, middle-income households have averages income of $\mathrm{GH} \notin 14,823.5$ while high-income households have average annual income of GH $£ 25,200.9$ (GSS, 2014). Table 1 shows that about $64.5 \%$ of the farmer households were low-income households with about 37.4\% having average annual income that is less than half of the annual average of the low-income group. About $27.6 \%$ of the respondents were within the middle-income group and $7.9 \%$ of respondent was within the high-income group.

\section{Yam varieties cultivated by farmers}

Farmers in the study locations cultivate many different yam varieties. Figure 1 shows the percentage distribution of more than 15 yam varieties cultivated by farmers. The five common white yam varieties cultivated include Pona/Punjo (15.9\%), Lariboko (11.7\%), Afasie (9.3\%), Asana (8.7\%) and Kparinjo (7.4\%). The predominance of yam cultivated by farmers varied across the three different study locations. In the Kintampo municipality, for instance, the top three varieties cultivated by farmers were Pona/Punjo (22.5\%), Afebetuye (11.2\%), and Dente/Ponjo (11.2\%) (Figure 2). Lariboko, Olando, and Pkarinjo, were the top three yam varieties cultivated by $27.8 \%, 12.7 \%$ and $12.5 \%$ of farmers in the East Gonja district, respectively (Figure 3). Factors such as market demand which is influenced by sweet taste, poundability, and storability were among the reason for the variation in preference of yam cultivars in the study locations. 


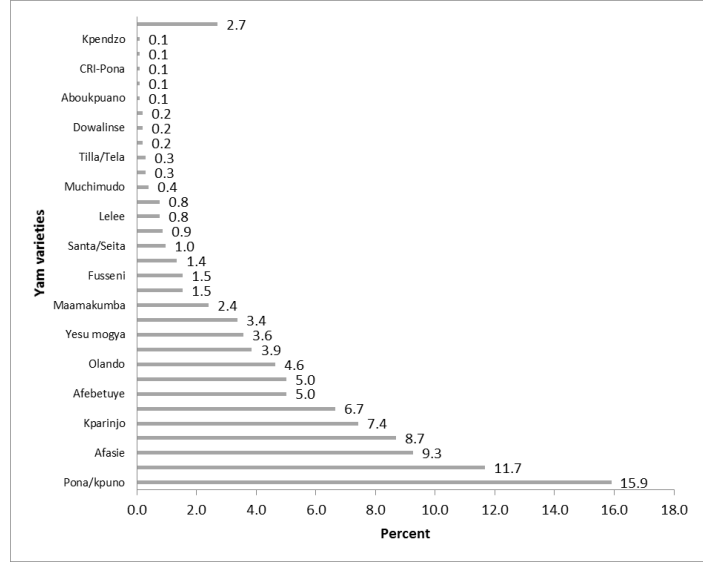

Fig. 1: Distribution of yam varieties cultivated by all respondents $(\mathrm{N}=380)$

Source: Field survey, 2015

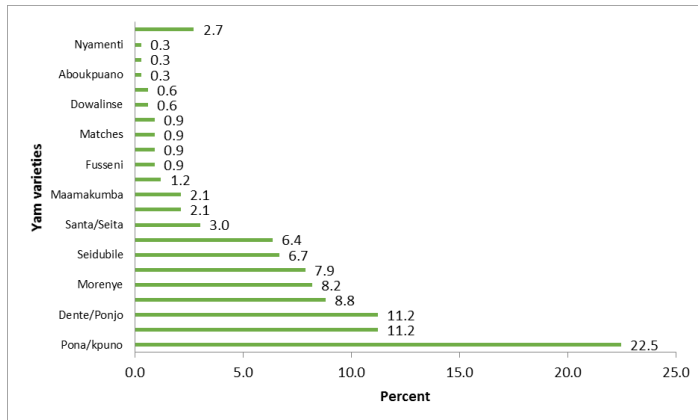

Fig. 2: Distribution of yam varieties cultivated in the Kintampo municipality

Source: Field survey, 2015



Fig. 3: Yam varieties cultivated in East Gonja District Source: Field survey, 2015
Figure 4 further shows that Asana (25.1\%), Afasie (15.5\%), and Pona/Kpuno (10.4\%) were the three main yam varieties cultivated by farmers in the Afram Plains district.

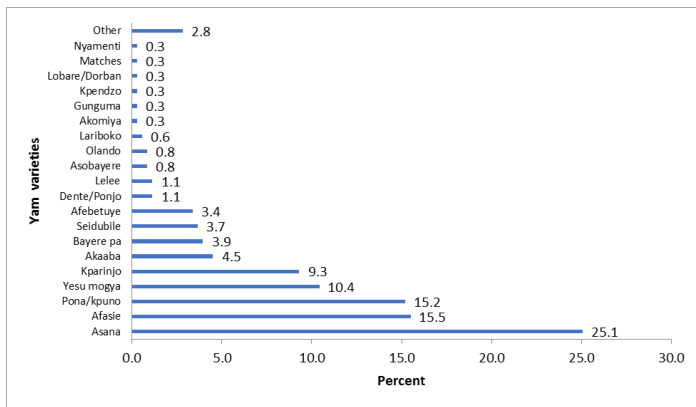

Fig. 4: Yam varieties cultivated in Afram Plains District Source: Field survey, 2015

Sources of seed yam for production

Yam farmers obtain seed yam from three main sources (i.e. own production, market and other farmers). Own production was the source of seed for $84.7 \%$ of yam farmers. This was followed by seed obtained from other farmers (7.7\%), and market sources (7.5\%). Other source such as MoFA was very insignificant $(0.1 \%)$ (Figure 5$)$. Interventions in the seed yam sector are not effective because they are mostly based on project as such the support truncates with the end of project interventions. Also, the minisett technology promoted by MoFA and other agencies has not received the needed adoption by farmers owning to the special care required for the minisetts and the need to cultivate the minisetts to develop microtubers for cultivation. Farmers are inpatients and indicated they would prefer using the period to cultivate micro-tubers to cultivate ware yam. Thus, there is a need for a commercial entity to fill the gap and perform that function. The percentage distribution of sources of seed 
yam to farmers were similar in all the study areas with the exception of Afram Plains district where the proportion of farmers who obtained seed yam from other farmers were $3.5 \%$ less than those who obtained seed yam from the market. Although own production is the main source of seed yam to farmers, all the respondents indicated that they purchased seed yam to supplement their seed used for planting in the previous farming season. They further indicated that whenever a new variety of yam is introduced on the market they purchase some to try on their farms. Own production of seed yam remains dominant partly because the market is unable to supply enough seed yam for sale. Farmers have no choice than to produce their own seed yam. Furthermore, the seed yam supplies to the informal market are surpluses of other farmers that may be of lesser quality. A study by Boadu et al. (2019) found that farmers are willing to pay for certified seed yam.

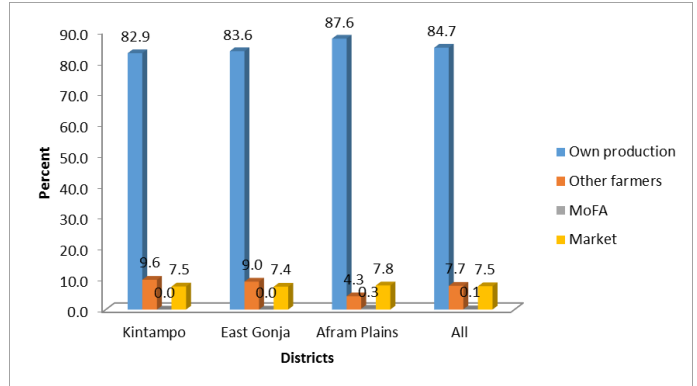

Fig. 5: Sources of seed yam to farmers

Source: Field survey, 2015

Quantities and value of seed yam obtained from own production

The quantities of seed yam obtained by farmers from own production for cultivation ranged from a minimum of 0.2 bunches to a maximum of 600 bunches (Table 2). On average, farmers obtained about 16.1 bunches of seed yam from own production for cultivation with a standard deviation of 39.7 . The majority of farmers (84.1\%) obtained less than 20 bunches of seed yam from their production. A similar distribution across the study locations was observed among farmers in all the districts.

TABLE 2

Quantity of yam sets obtained from own production (100 bunch)

\begin{tabular}{lllll}
\hline $\begin{array}{l}\text { Yam } \\
\text { sets }\end{array}$ & $\begin{array}{l}\text { All } \\
(380) \\
\%\end{array}$ & $\begin{array}{l}\text { Kintampo } \\
(123) \\
\%\end{array}$ & $\begin{array}{l}\text { East } \\
\text { Gonja } \\
(133) \\
\%\end{array}$ & $\begin{array}{l}\text { Afram } \\
\text { Plains } \\
(124) \\
\%\end{array}$ \\
\hline$<=20$ & 84.1 & 86.0 & 83.1 & 83.4 \\
$21-30$ & 10.1 & 7.2 & 12.6 & 10.0 \\
$41-60$ & 3.1 & 2.3 & 2.6 & 4.3 \\
$61-80$ & 0.8 & 1.3 & 0.3 & 0.9 \\
$81-100$ & 0.7 & 1.6 & 0.3 & 0.3 \\
$>100$ & 1.3 & 1.6 & 1.2 & 1.2 \\
Mean & 16.1 & 17.2 & 16.2 & 15.0 \\
SD & 39.7 & 53.9 & 37.0 & 25.1 \\
Min & 0.2 & 0.3 & 0.3 & 0.2 \\
Max & 600 & 600 & 400 & 300 \\
\hline
\end{tabular}

Source: Field survey, 2015

Furthermore, Table 3 presents farmers' estimation of the value of quantity of seed yam obtained from own production. About $77.9 \%$ of farmers estimated the value of own produced seed to be GHф 200 or less. The proportion of such farmers was greater in the East Gonja district (94.5\%) as compared to the Kintampo municipality (66.1\%) and Afram Plains district (70.7\%). 
TABLE 3

Estimated value of seed yam produced from own sources $(G H \phi)$

\begin{tabular}{lllll}
\hline Value & $\begin{array}{l}\text { All } \\
(380)\end{array}$ & $\begin{array}{l}\text { Kintampo } \\
(123)\end{array}$ & $\begin{array}{l}\text { East } \\
\text { Gonja } \\
(133)\end{array}$ & $\begin{array}{l}\text { Afram } \\
\text { Plains } \\
(124)\end{array}$ \\
\hline$<=200$ & 77.9 & 66.1 & 94.5 & 70.7 \\
$201-500$ & 18.4 & 26.1 & 2.6 & 28.2 \\
$501-1000$ & 2.1 & 2.9 & 2.3 & 1.2 \\
$>1000$ & 1.7 & 5.0 & 0.6 & 0.0 \\
Mean & 199.2 & 367.8 & 79.6 & 181.9 \\
SD & 600.8 & 1062.7 & 207.5 & 125.6 \\
Min & 10 & 10 & 10 & 10 \\
Max & 12000 & 12000 & 3000 & 600 \\
\hline
\end{tabular}

*GHф-1 US Dollar $(\$)=3.84$ Ghana Cedi $(\mathrm{GH} \phi)$ at the time of survey, 4/2015

Source: Field survey, 2015

An average value of $\mathrm{GH} \varnothing 199.2$ seed yam was obtained from own production with a standard deviation of 600.8. In all, an estimated value of seed yam obtained from own production ranged from $\mathrm{GH} \phi 10-\mathrm{GH} \phi 12,000$. Across the study locations, the maximum value of seed yam obtained from own production by farmers in the Kintampo municipality was four times higher than that obtained by farmers in the East Gonja district and 20 times higher than the value of seed yam obtained from Afram Plains district.
Quantity and estimated value of seed yam obtained from the market and other sources

TABLE 4

Quantity of seed yam obtained from market and other sources

\begin{tabular}{lllll}
\hline Value & $\begin{array}{l}\text { All } \\
(380) \\
\%\end{array}$ & $\begin{array}{l}\text { Kintampo } \\
(123) \%\end{array}$ & $\begin{array}{l}\text { East } \\
\text { Gonja } \\
(133) \\
\%\end{array}$ & $\begin{array}{l}\text { Afram } \\
\text { Plains } \\
(124) \\
\%\end{array}$ \\
\hline$<=20$ & 89.9 & 82.4 & 87.8 & 100 \\
$21-30$ & 1.9 & 2.9 & 2.4 & 0.0 \\
$41-60$ & 1.9 & 8.8 & 0.0 & 0.0 \\
$61-80$ & 2.5 & 5.9 & 2.4 & 0.0 \\
$81-$ & 0.6 & 0.0 & 1.2 & 0.0 \\
100 & 3.2 & 0.0 & 6.1 & 0.0 \\
$>100$ & 12.1 & 22.2 & 4.2 \\
Mean & 15.2 & 12.1 \\
SD & 44.6 & 21.3 & 59.6 & 3.3 \\
Min & 0.3 & 1.0 & 0.3 & 0.3 \\
Max & 300 & 70 & 300 & 15 \\
\hline
\end{tabular}

Source: Field survey, 2015

Table 4 shows that about $90 \%$ of farmers obtained up to 20 bunches of seed yam from the market and other sources such as other farmers and MoFA. With the exception of Afram Plains district where all the farmers obtained up to 20 bunches of seed yam from the market and other sources, the distribution was found to be similar in Afram Plains and East Gonja district. Also, an average of 15.2 bunches of seed yam was obtained by farmers from the market and other sources with a standard deviation of 44.6. The farmers were asked to estimate the amount spent on seed yam obtained from the market and other sources. The results are shown in Table 5. 
TABLE 5

Estimated value of seed yam obtained from the market and other sources ( $\mathrm{GH} \phi)$

\begin{tabular}{lllll}
\hline Value & $\begin{array}{l}\text { All } \\
(380)\end{array}$ & $\begin{array}{l}\text { Kintampo } \\
(123)\end{array}$ & $\begin{array}{l}\text { East } \\
\text { Gonja } \\
(133)\end{array}$ & $\begin{array}{l}\text { Afram } \\
\text { Plains } \\
(124)\end{array}$ \\
\hline$<=200$ & 77.9 & 66.1 & 94.5 & 70.7 \\
$201-500$ & 18.4 & 26.1 & 2.6 & 28.2 \\
$501-1000$ & 2.1 & 2.9 & 2.3 & 1.2 \\
$>1000$ & 1.7 & 5.0 & 0.6 & 0.0 \\
Mean & 122.3 & 122.7 & 63.6 & 233.7 \\
SD & 133.3 & 112.1 & 75.6 & 160.9 \\
Min & 10 & 20 & 10 & 10 \\
Max & 700 & 500 & 600 & 700 \\
\hline
\end{tabular}

Source: Field survey, 2015

About $77.9 \%$ of the farmers estimated the value of seed yam obtained from the market and other sources to be up to $\mathrm{GH} \phi 200$. An average of $\mathrm{GH} \phi 122.3$ was spent by farmers to obtained seed yam from this source with a standard deviation of 133.3. The average amount spent by farmers in the East Gonja and Afram Plains districts varied markedly from the overall average expenditure on seed yam obtained from the market and other sources. While an average of $\mathrm{GH} \phi 233.7$ was spent by farmers in the Afram Plains to obtain seed yam from the market and other sources their counterpart on the East Gonja districts spent an average of $\mathrm{GH} \phi 63.6$.

Estimated quantity demanded for seed yam An understanding of the quantity of seed yam demanded by farmers is an important decision and policy variable to helps seed entrepreneurs in their decision to participate in seed yam commercialization and also developing appropriate seed yam certification systems. The quantity of seed yam demanded (in monetary terms) was estimated as the summation of the product of the value of seed yam and quantity of seed yam obtained by farmers (equation 1).

TABLE 6

Estimated quantity demand for seed yam by farmers and district of respondents $(G H \phi)$

\begin{tabular}{|c|c|c|c|c|c|c|}
\hline \multirow{2}{*}{ Location } & \multirow{2}{*}{$N$} & \multirow{2}{*}{$\begin{array}{l}\text { Total quantity Demanded } \\
\text { Value }\end{array}$} & \multicolumn{2}{|l|}{ Own production } & \multicolumn{2}{|c|}{ Market/Other sources } \\
\hline & & & Value & $\%$ & Value & $\%$ \\
\hline Kintampo & 123 & $2,141,942.5$ & $2,131,379.5$ & 99.5 & 10,563 & 0.5 \\
\hline East Gonja & 133 & $310,883.1$ & $259,696.8$ & 83.5 & $51,186.3$ & 16.5 \\
\hline Afram Plains & 124 & $532,287.5$ & $508,642.0$ & 95.6 & $23,645.5$ & 4.4 \\
\hline All & 380 & $2,985,113.1$ & $2,899,718.3$ & 97.1 & $85,394.8$ & 2.9 \\
\hline
\end{tabular}

Source: Field survey, 2015 
The total quantity of seed yam valued at about GHф 2,985,113.1 was demanded by respondents for cultivation in the 2014 farming season. About $97 \%$ of this quantity demand was from own production with $3 \%$ (valuing $\mathrm{GH} \varnothing 85,394.8$ ) of it obtained from the market and other sources. While the Kintampo municipality has the highest quantity demand for seed yam (about GHф 2,141,942.5), only $0.5 \%$ was obtained from the market and other sources. The quantity demand for seed yam in East Gonja and Afram Plains districts was $\mathrm{GH} \varnothing$ $310,883.1$ and $\mathrm{GH} \varnothing 532,287.5$ with about $16 \%$ and $4.4 \%$ obtained from the market and other sources, respectively (Table 6).

Abroader picture of the quantity of seed yam demanded by farmers from the market and other sources is obtained when the results are extrapolated to consider all yam farmers in the study location. Data from MoFA/SRID (2015) estimated the area under yam cultivation in 2014 in the Kintampo municipality, East Gonja and Afram Plains districts to be 18,110, 13,954 and 25,776 hectares, respectively. As indicated earlier the average yam farm size cultivated by respondents in 2014 was 2.6, 1.7 and 1.9 hectares in the Kintampo municipality, East Gonja and Afram Plains districts, respectively (Table 1). Assuming that each farmer cultivated the estimated average yam farm size as per the respective study locations then it follows that on the average about 6,965 farmers were involved in 2014 yam production in Kintampo municipality. The resultant number of farmers involved in 2014 production in East Gonja and Afram Plains districts were 8,208 and 13,566, respectively. These estimated numbers of yam farmers in the study locations were used to predict quantity demanded for seed yam in the study locations based on ratio and proportions. The results are shown in Table 7.

A total quantity of seed yam valued at $\mathrm{GH} \varnothing 597,367.7, \mathrm{GH} \varnothing 3,158,925.9$ and $\mathrm{GH} \varnothing$ 2,586,894.0 were obtained by farmers from the market and other sources for cultivation by farmers in Kintampo, East Gonja and Afram Plains, respectively, in 2014. This shows the potentials for seed entrepreneurs and seed companied to take advantage of the existing market demand to participate in commercial seed production and supply system.

TABLE 7

Predicted quantity seed yam demanded by farmers in 2014 ( $\phi)$

\begin{tabular}{lllllll}
\hline \multirow{2}{*}{ Location } & \multicolumn{3}{c}{$\begin{array}{l}\text { Total Quantity } \\
\text { Demand }\end{array}$} & Own production & \multicolumn{3}{c}{ Market/Other sources } \\
\cline { 2 - 7 } & $N$ & Value & Value & $\%$ & Value & $\%$ \\
\cline { 2 - 7 } Kintampo & 6956 & $121,132,943.0$ & $120,535,575.3$ & 99.5 & $597,367.7$ & 0.5 \\
East Gonja & 8208 & $19,185,928.0$ & $16,027,002.1$ & 83.5 & $3,158,925.9$ & 16.5 \\
Afram Plains & 13566 & $58,233,970.0$ & $55,647,076.0$ & 95.6 & $2,586,894.0$ & 4.4 \\
All & 28730 & $198,552,841.0$ & $192,872,861.9$ & 97.1 & $5,679,979.1$ & 2.9 \\
\hline
\end{tabular}

Source: Field survey, 2015 


\section{Conclusions and recommendations}

The study analysed the varieties, source and quantities of seed yam demanded by farmers for cultivation in order to inform policies aimed at ensuring adequate supply of quality seed yam of desirable varieties at an affordable price to enhance yam productivity for improved income and livelihoods. The study identified Pona/Punjo, Lariboko, Asana, Afebetuye, Dente, Olondo and Kparinjo as the yam varieties mainly cultivated by farmers with high market demands. The study finds that own production remains the major source of seed for yam farmers, although all the farmer respondents indicated they purchased some amount of seed yam from other farmers and the market to supplement their own produced seeds. The estimated value of quantity of seed yam demanded by farmers in 2014 amounted to $\mathrm{GH} \notin 198,552,841.0$ in the study locations. About GHd 5,679,979.1 worth of quantities of seed yam was obtained from the market/other farmers.

Based on these findings, it is recommended that commercial seed yam certification system should target the identified yam varieties in this study. The varieties could be the target for yam breeding activities to multiply and increase the availability of quality seed yam to farmers. The study has also demonstrated the existence of market potential for commercial seed production and supply in Ghana. Commercial seed producers could target meeting existing market demands. The market share could be increased overtime if they produce and supply quality seed yam to farmers. This would reduce the proportion of seed yam obtained by farmers from own sources and also make available seed yam for new farmers to enhance productivity.

\section{Acknowledgement}

The authors are grateful to farmers who participated in the survey. This study was funded by Bill and Melinda Gates Foundation through Yam Improvement for Income and Food Security in West Africa (YIIFSWA) project which made this paper possible as part of the Ph.D. work of the lead author.

\section{REFERENCES}

Aidoo, R. (2009) "An analysis of yam consumption patterns in Ghanaian urban communities", $\mathrm{Ph}$. D thesis submitted to the Department of Agricultural Economics, Agribusiness and Extension, Kwame Nkrumah University of Science \& Technology, Kumasi, Ghana.

Aighewi, B. \& Maroya, N. (2013) Increasing Quantity and Improving Quality of Seed Yams to Boost Yam Production. Presentation at YIIFSWA Workshop, Salaga, East Gonja, Ghana. 23-25 October, 3013.

Aighewi, B.A., Maroya, N.G. \& Asiedu, R. (2014) Seed yam production from minisetts: A training manual. IITA, Ibadan, Nigeria.

Almekinders, C. (2001) Management of crop genetic diversity at community level. Germany, GTZ: Esch- born.

Almekinders, C., \& de Boef. W. (2000) Encouraging diversity: The conservation and development of plant genetic resources. London: Intermediate Publications Ltd.

Anaadumba P., (2013) Analysis of incentives and disincentives for yam in Ghana. Technical notes series, MAFAP, FAO, Rome

Asumugha, G. N, M. E, Njoku B. C, Okoye, O.C. Aniedu, M.C. Ogbonna, H.N. Anyaegbunam, O. A. Akinpelu, O. Ibeagi \& Amaefula, A. (2008) Analysis of the supply of seed yam in Nigeria. African Journal of Business Management 3 (1), 028 -031. 
Badstue, L. B., Bellon, M. R., Berthaud, Dagoberto Flores J. A. R. \& Jua Rez, X. (2006) The Dynamics of Farmers' Maize Seed Supply Practices in the Central Valleys of Oaxaca, Mexico. World Development 35 (9), 1579 1593.

Bellon, M. (2004) Conceptualizing interventions to support on-farm genetic resource conservation. World Development 32 (1), 159 - 172.

Cromwell, E.A. (ed.), (1990) 'Seed diffusion mechanisms in small farmer communities: lessons from Asia, Africa and Latin America', Network Paper No.21, Agricultural Administration (Research and Extension) Network, London: Overseas Development Institute.

Ezeh, N. (1991) "Economics of Seed yam production from Minisetts at Umudike, South Eastern Nigeria: Implications for Commercial Growers." Proc. of $9^{\text {th }}$ Int. Symp. of Intern. Soc. for Tropical Root Crops, IITA, Ibadan.

Ghana Statistical Services. (2014) Ghana Living Standards Survey Report of the Round Six (GLSS 6), August 2014.

Ghimire, S., Mehar, M. \& Mittal, S. (2012) Influence of Sources of Seed on Varietal Adoption Behavior of Wheat Farmers in Indo-Gangetic Plains of India. Agricultural Economics Research Review 25, 399 - 408.

ICRISSAT (2009) Seed Systems-Enhancing the availability of quality seed of improved varieties for smallholder farmers.

IITA. (2012) New Project to Invest US\$12 Million to Boost Yam Productivity in Ghana and Nigeria. April 2012

IITA. (2014) Yam Improvement for Income and Food Security in West Africa (YIIFSWA)

Project Document. International Institute of Tropical Agriculture.
Jarvis, D. I., Myer, L., Klemick, H., Guarino, L., Smale, M., Brown, A. H. D., et al. (2000) A training guide for in-situ conservation onfarm. Version 1. Rome: International Plant Genetic Resources Institute (IPGRI).

Louwaars N.P. \& De Boef W.S. (2012) Integrated seed sector development in Africa: A conceptual framework for creating coherence between practices, programs, and policies. Journal of Crop Improvement 26, 39 - 59.

MEDA (2011) 'Ghana yam market, sub-sector and value chain assessment'. Final Study Report for the Bill \& Melinda Gates Foundation, $13^{\text {th }}$ May 2011.Statistics, Research and Information Directorate of Ministry of Food and Agriculture, Ghana (2012). Information Directorate of Ministry of Food and Agriculture, Ghana (2012).

MiDA (2010) 'Investment Opportunity Ghana Yam Seed Production'. Millennium Development Authority Opportunity Paper, Ghana.

Mignouna, B. D., Abdoulaye, T., Alene, A.D., Asiedu, R., \& Manyong, V. M. (2014a) Characterization of Yam-growing Households in the Project Areas of Ghana. International Institute of Tropical Agriculture (IITA).

Mignouna, D.B., Akinola, A. A., Suleman, I., Nweke, F \& Abdoulaye, T. (2014b) Yam: a cash crop in West Africa. YIIFSWA Working Paper Series No. 3. Yam Improvement for Income and Food Security in West Africa.

Ministry of Food and Agriculture (2015) Statistics Research and Information Directorate.

Nweke, F., Aidoo, R., Okoye, B. (2013). Yam Consumption Patterns in West Africa. Final Report for BMGF. July 2013.

Otoo, E. (2003) Farmer Participatory Breeding-A Waste or a Must: The $13^{\text {th }}$ Symposium of International Society of Tropical Root Crops (ISTRC), Arusha, Tanzania-9-19 ${ }^{\text {th }}$ November, 2003. 
Otoo, E., Klein, U., Boadu, P. \& Sarpong, S. (2013) 'Ghana: In-depth value chain analysis'. Second draft report for Bill \& Melinda Gate foundation

Regassa F. (2000) Community seed banks and seed exchange in Ethiopia: A farmer led approach. In E. friis-Hansen and B. Sthapit (eds), Participatory approaches to the conservation and use of plant genetic resources, 142 - 148. IPGRI, Rome.

Singh, G., Asokan, S. R. \& Asopa, V. N. (1990) Seed Industry in India - A Management Perspective. Oxford \& IBH Publishing Co. (Pvt.) Ltd., New Delhi.

Sthapit, B., Ram, R., Pashupati, C., Bimal, B. \& Pratap. S. (2008) Informal seed systems and on-farm conservation of local varieties.
In Farmers, seeds and varieties: supporting informal seed supply in Ethiopia, ed. M.H. Thijssen, Z. Bishaw, A. Beshir, W. and W.S. de Boef, 133 - 137. Wageningen: Wageningen International.

Tripp, R. (2003) How to cultivate a commercial seed sector. Sustainable agriculture in the Sahel. Paper prepared for the symposium 'Sustainable Agriculture in the Sahel', Bamako, Mali, 1-5 December 2003.

United Nations. (2015) Transforming Our World: The 2030 Agenda for Sustainable Development

Verma S. \& Sidhu, M. S. (2009) Sources, Replacement and Management of Paddy Seed by Farmers in Punjab. Agricultural Economics Research Review 22, 323 - 328. 